Discourse and Communication for Sustainable Education, vol. 3, pp. 41-62, 2012

\title{
CAN EDUCATION FOR SUSTAINABLE DEVELOPMENT ADDRESS CHALLENGES IN THE ARAB REGION? EXAMINING BUSINESS STUDENTS' ATTITUDES AND COMPETENCES ON EDUCATION FOR SUSTAINABLE DEVELOPMENT: A CASE STUDY FROM LEBANON
}

\author{
Nancy Kanbar \\ Notre Dame University - Louaize, Lebanon
}

\begin{abstract}
The population growth together with the unsustainable consumption pattern is putting increasing stress on the planet's natural resources. The increasing realisation that humans are harming the environment is taking the form of a global movement intended to change behaviour towards sustainability, now recognised as a framework that links humans to nature. Continuous exploitation of natural systems in the Arab region leads to environmental damages that negatively affect human well-being. This article presents a case study from the Reorient University Curricula to Address Sustainability (RUCAS) Tempus project funded by the European Commission. It highlights the results of an empirical study in the Faculty of Business Administration and Economics (FBAE) at Notre Dame University - Louaize (NDU) in Lebanon. The main objective is to assess the need for education for sustainable development (ESD) through an examination of students' attitudes and competences with the aim of reorienting university curricula to address sustainability. A framework based on the pillars of learning set by UNESCO was developed to measure ESD attitudes and competences. The main findings reveal the need to reorient university courses to address sustainability issues. Attitudes questions suggest that relatively high numbers of students are not aware of their responsibilities for environmental problems, which imply the necessity for a revised curriculum where courses are restructured to inform students of their responsibility for their environment and the quality of life. The results show that the disciplinary competences are significantly lower than the five pillars of learning (general competences) which indicate that the FBAE needs to reorient its curricula to infuse ESD into its programmes through the development of effective pedagogical approaches, teaching methodologies as well as learning materials.
\end{abstract}

Key words: education for sustainable development, attitudes and competences, pillars of learning, environmental challenges, business students, the Reorient University Curricula to Address Sustainability (RUCAS) Tempus project 


\section{Background}

Environmental resources, 'common' in nature, are being unsustainably used causing a large-scale environmental crisis. Our current global problems are caused by three crises: the financial crisis, food problem and climate change. The world is suffering many problems with serious threats to human well-being and sustainability (Costanza, 2011a). There is a clear need to change the status quo of the world through sustainable development (SD). Sustainability is an evolving paradigm that necessitates an understanding of the interconnections and interdependencies among ecological, economic and social systems (Schmuck \& Schultz, 2002; Kemp, Parto, \& Gibson, 2005; Munier, 2005; Von Der Heidt \& Lamberton, 2011). The United Nations Educational, Scientific and Cultural Organisation (UNESCO) views SD as having a different vision of the world (UNESCO, 2005). Reframing the way humans view nature as an essential component to our social and economic well-being is needed to build a sustainable future for the next generations (Costanza, 2011b). The sustainability paradigm is emerging as a megatrend affecting policies at all levels of governments, businesses as well as educational institutions (Lubin \& Esty, 2010). We need a new way to view humanity and the rest of nature, a shift in moral values and new commitments of the future generations to finding sustainable solutions. With the significant increase in the global threats, education has a fundamental role to play in personal and social development (Delors, 1996). Since education is a motor for change, the great task educators are called for is to provide the new generation students across all disciplines - with a vision of education that seeks to empower them to assume responsibility for creating a sustainable future, and this is education for sustainable development (ESD) by definition.

\section{ESD: Its roots, objectives and characteristics}

According to UNESCO (n.d.), though ESD can be seen as associated with the many SDrelated educations, it has its roots in environmental education (EE). The founding documents are the Tbilisi Declaration for EE and Chapter 36 of Agenda 21 for ESD. In October 1977, the world's first intergovernmental conference on EE took place in Tbilisi, Georgia. This event and the subsequent publications continue to provide the blueprint for the development of EE (UNESCO, 1978). In June 1992, the United Nations (UN) organised a conference on environment and development (UNCED), the Earth Summit at Rio de Janeiro, Brazil. The outcomes of the Rio agreements were combined in Agenda 21 , a major action programme setting out what nations should do to achieve SD in the 21st century. There were implications for EE throughout this document, particularly in Chapter 36 that established the basis for action in EE for SD. One of the major outcomes of the conference for educators is the recommendation that environment and development education should be incorporated as an integral part of learning (UN, 1992).

During the post-Rio decade, conferences and meetings which focused on SD and the role of education continue to emphasise the need for capacity-building and continuous engagement in sustainability. In recognition of the importance of ESD, the United Nations General Assembly, through its Resolution 57/254, in December 2002, declared a Decade of Education for Sustainable Development (DESD) (2005-2014) and designated UNESCO as the lead agency. Since the launching of the DESD, many sustainability 
issues have been integrated in education. The UNESCO framework of the DESD scheme suggests that ESD requires the integration of all dimensions of SD including social, environmental, cultural and economic. Through ESD plans, students should acquire various skills (critical and creative thinking, communication, conflict management and problem-solving strategies as well as project assessment) to actively contribute to the life of society, be respectful of the Earth and life in all its diversity and be committed to promoting democracy and peace (UNESCO, 2005). To achieve those objectives, the DESD focuses on (a) promoting quality education and encouraging citizens to live sustainably; (b) reorienting education programmes to focus on the development of knowledge, skills, perspectives and values related to sustainability; (c) building awareness of the concept of SD through community education and the media, in order to make it possible to develop enlightened, active and responsible citizenship locally, nationally and internationally; (d) providing practical training and continuing education to teacher trainers, pre-service and in-service teachers in making SD a reality (UNESCO, 2005; Spiropoulou, Antonakaki, Kontaxaki, \& Bouras, 2007). In addition, the DESD exerts concerted efforts to create synergies with other global initiatives, such as the United Nations Millennium Development Goals (MDGs), the United Nations Literacy Decade and the Literacy Initiative for Empowerment (LIFE). In declaring these global initiatives, the international community clearly recognises that a change towards SD and a better quality of life start with education.

\section{Rationale: The need for ESD in the Arab region}

Efforts to ensure SD in the Arab region are challenged by increased demands on already constrained natural resources. If Arab countries maintain their slow trajectory towards SD, an estimated 124 million people in the Arab region will lack access to basic sanitation in 2015, with about half of these living in the Arab least developed countries (Economic and Social Commission for Western Asia [ESCWA], 2010). The global environmental challenges are becoming significant obstacles to human well-being, a situation that calls for the redirection of national development policies that highlight sustainability. Because threats to the environment are threats to development (World Bank, 2012), the growing environmental challenges in the Arab region are negatively impacting sustainability at all levels.

Population in Arab countries is estimated to be about 395 million people by 2015 (the United Nations Development Programme [UNDP], 2009). The rapid increase in population, together with the changing consumption patterns, put strong pressures on the carrying capacity of already fragile Arab lands (Abahussain, Abdu, Al-Zubari, ElDeen, \& Abdul-Raheem, 2002). The population growth problem is accompanied by intensive urban migration, creating burdens on infrastructure and resulting in congested and unhealthy living conditions in many Arab cities. Additionally, population growth and socio-economic development have generated a considerable increase in water demands. While the population in the Arab region accounts for five per cent of the world population, this region is the source of less than one per cent of the world's renewable fresh water (ESCWA, 2010). Water shortage and deteriorating water quality are the most significant challenges that confront well-being in the Arab region (UNDP, 2009). Population increase, land-use and land cover change and climate change are expected 
to contribute to accelerated water scarcity and desertification. The majority of Arab lands are dominated by drylands, and a major challenge in these ecosystems is desertification. "Desert has swallowed up more than two-thirds of total land area of the region" (UNDP, 2009, p. 3). This has reduced the availability of arable land, leading to reduction in agricultural production, malnutrition, poor health, poverty and sometimes creating social and political conflicts. Another challenge in many Arab cities is the air pollution level that exceeds World Health Organization (WHO) standards and negatively affects the economic and health sectors of Arab population (Arab Forum for Environment and Development [AFED], 2011). The Arab region is already the most water-scarce region in the world, which makes it among the most vulnerable to the impacts of climate change (Arab Climate Resilience Initiative, 2010). Climate change may cause problems in many ways, such as worsening of the water shortage problem, reducing agricultural production, intensifying urban migration, causing further losses of biodiversity, reducing levels of economic activity and threatening human well-being (UNDP, 2009).

Facing the increasingly significant environmental problems and in an effort to achieve ESD objectives in the Arab region, in the period 2006-2007 the UNESCO Regional Bureau for Education in the Arab States in Beirut (Lebanon) has carried out a study to explore mechanisms to be adopted in order to ensure sustainability in the region. The study identified many SD challenges in the Arab region and revealed that Higher Education Systems in the region are facing major problems that are adversely affecting their ability to achieve sustainability (Makrakis, Kostoulas-Makrakis, \& Kanbar, 2012). According to the UNESCO report (2007), "there is no evident progress in DESD implementation, be it regional or national, in the Arab region" (p. 60) - an alarming finding for all Arab countries. The Arab Millennium Ecosystem Assessment report comes out recently to show that efforts to ensure sustainable development in the Arab region are hindered by many ecosystem challenges (Kanbar, in press).

\section{Objectives}

With a lack of progress in implementing ESD in the Arab region, it is timely that Arab countries regard education as the cornerstone to achieve the goals of sustainability. This article intends to explore ESD-related issues in higher education in the Arab region. The research presents a case study from the FBAE at NDU in Lebanon to assess the need to reorient university curricula to address sustainability. It reports the results of the RUCAS Tempus project. In investigating this topic, this main objective of the study is to assess the need for ESD through an examination of the ESD students' attitudes and competences with the aim of reorienting university curricula to address sustainability. This objective will be achieved by answering the following research questions: What are the sources of information about SD students have used? What kinds of actions have students done lately for SD reasons? What teaching and learning methods are being currently used in our university programmes? What are the current attitudes and ESD competences that students currently have?

These research questions will be answered by drawing on the results of an empirical study among 227 undergraduate students in the FBAE at NDU, which was designed based on the five pillars of learning set by the UNESCO, as described in the next section. 


\section{RUCAS conceptual framework}

Based on the UNESCO recommendation that educational programmes of universities in terms of curriculum and teaching methods should infuse ESD to sensitise students and other stakeholders towards sustainability, the RUCAS Tempus project was born in October 2010. RUCAS comes at the middle of the DESD, and its relevance is strengthened by the Bonn Declaration held in Germany in 2009 in which it was declared that action should be taken to re-orient education and training systems to address sustainability concerns through coherent policies at national and local levels (UNESCO, 2009). The concept of sustainability requires educational institutions to rethink their missions and to restructure their courses, research priorities, community outreach and campus operations. Within this context, a number of European higher education institutions (HEIs) who have developed expertise in the field of ESD have joined efforts with six HEIs from Lebanon, Jordan and Egypt along with active NGOs to form a consortium whose aim is to revise university curricula to address sustainability. The ESD issues raised by the UNESCO Regional Bureau for Education in the Arab States study fit into the development strategies of the three Arab countries participating in RUCAS. Further, ESD, as an inter-disciplinary area, covers many prioritised disciplines both nationally and regionally. The RUCAS project adopts a multi/inter-disciplinary and systemic approach that aims to design and implement a model that underlines sustainability issues into higher education curricula and develop resources to support university teaching staff and management to embed sustainability across curricula in the disciplines of educational sciences, social sciences, business and economics, engineering and applied sciences.

With the evolving and interdisciplinary nature of the concept of sustainability, ESD is based on the principles and values that underlie SD, and it deals with four dimensions of sustainability: environment, society, culture and economy (UNESCO, 2007). ESD uses a variety of pedagogical techniques that promote participatory learning and higher-order thinking skills. It is locally relevant and culturally appropriate; it is based on local needs, perceptions and conditions, but acknowledges that fulfilling local needs has international consequences. ESD promotes lifelong learning and engages formal, non-formal and informal education. It addresses content, taking into account the context, global issues and local priorities. It builds civil capacity for community-based decision making, social tolerance, environmental stewardship and a good quality of life. ESD programmes reflect the distinctive environmental, social, cultural and economic conditions of each locality. In spite of their differences, all programmes should be based on five fundamental pillars of learning to provide quality education and foster SD (four as set out in the Delors' report (1996) and the fifth pillar added by UNESCO). Thus, achieving SD requires:

- recognition of the challenge of sustainability (learning to know);

- acting with determination (learning to do);

- collective responsibility and constructive partnership (learning to live together);

- the indivisibility of human dignity (learning to be);

- individual and collective actions (learning to transform oneself and society).

According to the Delors' report (1996), learning to know emphasises learning to learn, so as to benefit from the opportunities education provides. Learners build their knowledge, values, cognitive skills and reasoning in order to develop critical thinking, acquire tools for understanding the world and sustainability issues. Learning to do entails 
acquiring the competence to deal with a variety of situations and to work in teams. It is about knowledge, values and knowing how to actively engage in order to be an actor as well as a thinker, understand and act on global and local SD issues, acquire technical and professional training, apply learned knowledge and be able to act creatively and responsibly. Learning to live together is about developing an understanding of other people and an appreciation of interdependence in a spirit of respect for the values of pluralism, mutual understanding and peace. This pillar of learning has to do with knowledge, values, social skills and social capital for international, intercultural and community cooperation in order to work together in increasingly multi-cultural societies; develop an understanding of other people and their histories, traditions, beliefs and values; tolerate, respect and celebrate difference and diversity in people; respond constructively to the cultural diversity and economic disparity around the world and be able to cope with conflict situations. Learning to be emphasises the development of one's personality and the ability to act with greater autonomy, judgment and personal responsibility. It assumes that each individual has the opportunity to develop his/her full potential, and it is based on the principle that education is for enabling individuals to learn, seek, build and use knowledge to address local and global problems. This pillar of learning relates to knowledge, values, personal skills and dignity for personal and family well-being in order to see oneself as the main actor in defining positive outcomes for the future, encourage discovery and experimentation, acquire universally shared values, develop one's personality and be able to act with greater autonomy and personal responsibility. As for the fifth pillar added by UNESCO, learning to transform oneself and society, it recognises that individuals working separately and together can change the world and that a quality education provides the tools to transform societies, because of the way it equips humans with knowledge, values and skills for transforming attitudes and lifestyles. Achieving SD requires individual and collective actions, active citizenship, future thinking, responsible lifestyles and sharing of resources. ESD empowers people to assume responsibility for creating and enjoying a sustainable future. This reflects a synergy of cognitive, practical, personal and social skills to bring about sustainability in order to promote behaviours that minimise our ecological footprint; be respectful of the Earth and life in all its diversity; act to achieve social solidarity and promote democracy.

\section{Research methods}

\section{Subjects}

Students were selected from the FBAE at NDU for two main reasons. First, FBAE is the largest faculty at NDU in terms of numbers of students and faculty members. Second, it has been suggested in the literature that conventional curricula of business schools reproduce socially and ecologically unsustainable values of affluent consumer society (Von Der Heidt \& Lamberton, 2011). Businesses, main polluters and consumers of natural resources, are major causes of unsustainability (Intergovernmental Panel on Climate Change [IPCC], 2007). Thus, to ensure a transition to sustainability requires business graduates to acquire competences as an essential component of a real solution. It is at the university level that graduates can gain these competences. 
To examine ESD attitudes and competences for business students, questionnaires were distributed to different faculty members in the FBAE who teach classes that encompass different business concentrations; mainly economics, finance, accounting, management, marketing and human resources. Thus, a cluster of classes was selected to cover all the students in the FBAE. A representative sample of 250 students was targeted. The response rate was $90.8 \%$ yielding 227 usable responses. Respondents were reminded that their responses are totally voluntary and strictly confidential. No monetary incentives were offered.

\section{Study instrument}

A framework to measure ESD students' attitudes and competences was developed to be used as a guide for the design and validation of ESD-related competences for students at the university level (Makrakis et al., 2012). The clusters adopted for the general competences were based on the Delors' report (1996), which recognises the four pillars for education: 1) learning to know; 2) learning to do; 3) learning to be and 4) learning to live together. We also added 'learning to transform oneself and society' that has been introduced by UNESCO as the fifth pillar. A pilot test with a group of 177 students from four faculties (Faculty of Business Administration and Economics (FBAE), Faculty of Natural and Applied Sciences (FNAS), Faculty of Humanities (FH) and Faculty of Engineering (FE) was undertaken at NDU to test the clarity of instructions, appropriateness of the response set and face validity of the items. The questionnaire was finalised, and 3757 students from the 12 participating universities in RUCAS were surveyed to examine the extent to which ESD attitudes and competences were acquired by students before starting the infusion of sustainability issues in the curricula. This article reports the results of the survey for the sample of undergraduate students at the FBAE at NDU (227 students).

The questionnaire consisted of six pages of questions to be completed mainly by Likert scale response statements, yes/no items and ranking questions. It asked about the country and the institution where the survey was conducted, it asked about the student's discipline and gender. It included questions on SD courses taken by the student; asked the student to rank the sources of information related to SD, rank the actions the student has done lately for SD reasons and rank the different teaching and learning methods that are being currently used in the university programmes. Additionally, the questionnaire attempts to assess the respondents' preference of the four functions of education, namely, to replicate the existing society and culture, to train people for future employment, to help people develop their potential and to encourage change towards a fairer society and a better world. Current students' attitudes towards ESD were measured using ten Likert scale items. The five pillars of learning (ESD general competences) were measured using fifty-four Likert scale items specifically designed for this study to include the five pillars of learning. Finally, eighteen items measure ESD disciplinary competences (business/economics in the case of this study) that students currently have. 


\section{Measurement of key variables}

Based on the conceptual model of the study, many variables are included to explore how they are causally prior to ESD students' attitudes and competences. These variables include gender, questions that ask students whether they have taken courses or assignments that deal with SD issues, sources of information related to SD, actions students have done lately for SD reasons and different teaching and learning methods that are being currently used in university programmes. Dichotomous $(0,1)$ dummy variables were created for gender and variables about courses or assignments that deal with SD issues. As for ranking the sources of information related to SD, students were asked to give a rank of 1 to the most used source. Zero was entered if no rank was given. Students were also asked to select all the actions they had done lately for SD reasons. Here, a dichotomous scale was used where zero was entered if the action was not selected and 1 if the action was selected. For the ranking of the different teaching and learning methods used in university programmes, students were given a list of ten methods and they had to rank them from one to ten with one being the most frequently used. A value of zero was given in the case of no rank.

Students' ESD attitudes were assessed through a series of items in the survey on a six-point rating scale (strongly disagree, moderately disagree, slightly disagree, slightly agree, moderately agree and strongly agree). Also, a six-point rating scale (not at all, poor, fair, good, very good and excellent) was used to assess general and disciplinary competences. Attitude scales and competence scales (for the five pillars of learning) were constructed by adding together all non-missing responses and dividing by the number of valid responses. This resulted in scales in the same range as the original variables (1-6). For all scales, the higher the values, the more the individual adheres to that attitude or competence. The scale was reversed for some attitude items to ensure all items follow the same direction, where a higher score means pro-environmental attitudes. All questionnaires were carefully edited to confirm that there were no obvious outliers. Responses were entered into Statistical Package for the Social Sciences (SPSS) statistical data editor. A quality check was conducted and statistical diagnostics that measure central tendencies and dispersion was applied to the data.

\section{Main findings}

\section{Students' profile and ESD literacy}

The analysis of the data revealed that $49.3 \%(n=112)$ of the students were females and $49.3 \%(n=112)$ were males. Only three students did not respond to the gender question. The majority of the respondents $(75.3 \%)$ have taken a course that includes some issues relevant to $\mathrm{SD}$, and many respondents $(58.6 \%)$ have taken a course that relates directly to SD. A percentage of $57.3 \%$ have done a course assignment or project that concerns SD.

When asked about the sources of information related to SD, the majority of the students $(68.7 \%)$ ranked the internet as the most used source of information about SD they had used. Thirty per cent of the sample ranked university courses as the second most important source of information related to SD. A relatively smaller percentage $(27.8 \%)$ ranked newspapers as the third source of information about SD. A small per- 
centage $(8.4 \%)$ noted that TV is the fourth source. An even smaller percentage $(7 \%)$ gave an unclassified answer suggesting that publications/brochures and magazines, events such as conferences, fairs/exhibitions and festivals; as well as conversations with friends/ family and colleagues might be ranked as the fifth, sixth and seventh source of information related to SD respectively. Radio and special interest groups were ranked eighth and ninth respectively (Table 1 ).

Table 1. Sources of information about SD students have used

\begin{tabular}{|c|c|c|c|c|c|c|c|c|c|c|c|}
\hline Source of information & 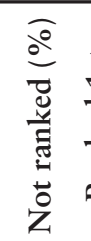 & 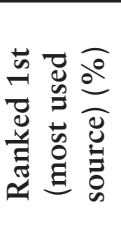 & 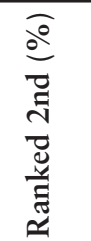 & 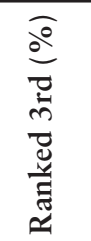 & 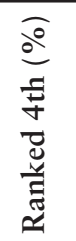 & 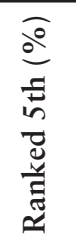 & 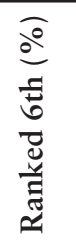 & 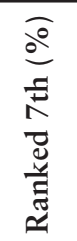 & 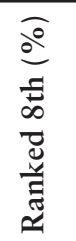 & 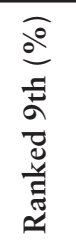 & 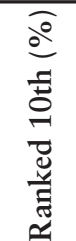 \\
\hline Newsp & 22.9 & 10.6 & 12.8 & 27.8 & 7.5 & 6.2 & 3.1 & 2.6 & 3.1 & 1.8 & 1.8 \\
\hline The internet & 5.7 & 68.7 & 13.7 & 6.6 & 3.5 & 0.9 & & & 0.4 & 0.4 & \\
\hline University courses & 18.5 & 22.5 & 30.0 & 13.7 & 5.3 & 5.3 & 0.4 & 2.6 & & 1.8 & \\
\hline TV & 20.3 & 20.7 & 18.1 & 21.1 & 8.4 & 4.0 & 2.2 & 1.3 & 3.5 & & 0.4 \\
\hline $\begin{array}{l}\text { Publications/brochures/ } \\
\text { magazines }\end{array}$ & 20.3 & 12.3 & 19.4 & 20.3 & 6.2 & 7.0 & 6.2 & 3.1 & 3.1 & 1.8 & 0.4 \\
\hline $\begin{array}{l}\text { Events (conferences, } \\
\text { fairs/exhibitions, } \\
\text { festivals, etc.) }\end{array}$ & 28.6 & 4.4 & 17.2 & 19.8 & 4.8 & 4.8 & 7.0 & 4.8 & 4.8 & 3.5 & \\
\hline $\begin{array}{l}\text { Conversations with } \\
\text { friends/family/colleagues }\end{array}$ & 21.6 & 15.9 & 17.2 & 12.8 & 6.6 & 4.8 & 4.4 & 7.0 & 4.4 & 5.3 & \\
\hline The radio & 30.0 & 3.1 & 10.1 & 21.1 & 4.8 & 5.7 & 6.2 & 6.2 & 6.6 & 5.7 & 0.4 \\
\hline & 29.5 & 6.6 & 10.1 & 21.1 & 2.2 & 4.4 & 4.0 & 4.4 & 5.3 & 11.0 & 1.3 \\
\hline
\end{tabular}

Table 2 suggests that the top three sources of information about SD issues are: the internet $(68.7 \%$ ranked it number one), university courses $(22.5 \%$ ranked them number one) and TV (20.7\% ranked it number one). When asked about the second rank, the order of these top three sources of information changed; university courses have now the highest percentage, followed by TV and then the internet. The third rank places TV first, followed by university courses and then the internet.

Table 2. The top three sources of information about SD according to rank one as shown in Table 1

\begin{tabular}{lcccccc}
\hline \multirow{2}{*}{ Source of information } & \multicolumn{2}{c}{ Rank 1 } & \multicolumn{2}{c}{ Rank 2 } & \multicolumn{2}{c}{ Rank 3 } \\
\cline { 2 - 7 } & $\mathbf{N}$ & $\mathbf{\%}$ & $\mathbf{N}$ & $\mathbf{\%}$ & $\mathbf{N}$ & $\mathbf{\%}$ \\
\hline The internet & 156 & 68.7 & 31 & 13.7 & 15 & 6.6 \\
\hline University courses & 51 & 22.5 & 68 & 30.0 & 31 & 13.7 \\
\hline TV & 47 & 20.7 & 41 & 18.1 & 48 & 21.1 \\
\hline
\end{tabular}




\section{Actions students have done for $S D$ reasons}

Students were asked to select all the actions they had done lately for SD reasons. Of the nine actions they were asked about, only three sustainable actions were selected by the majority of the students (about half the sample or more). Results show that $74.4 \%$ of the students indicated that they switched off unnecessary lights, $67 \%$ indicated that they used energy saving light bulbs, and about half of the sample $(49.8 \%)$ indicated that they donated money to charities. A large percentage of students $(87.7 \%)$ did not refuse to take a plastic bag from the supermarket, $80.2 \%$ did not do any form of voluntary work in their community. In addition, $75.3 \%$ have not purchased eco-labelled and fair products, $72.2 \%$ have not recycled cans, glass or paper. Furthermore, $69.6 \%$ have not used carpooling. Also, 54.2\% have not purchased environmentally friendly products (Table 3).

Table 3. Actions done during the past month for sustainable development reasons

\begin{tabular}{lcc}
\hline $\begin{array}{c}\text { Have you done any of the following actions during } \\
\text { the past month for SD reasons? }\end{array}$ & $\begin{array}{l}\text { Yes } \\
(\mathbf{\%})\end{array}$ & $\begin{array}{l}\text { No } \\
(\boldsymbol{\%})\end{array}$ \\
\hline Switched off unnecessary lights & 74.4 & 25.6 \\
\hline Purchased eco-labelled and fair-trade products & 24.7 & 75.3 \\
\hline Recycled cans, glass or paper & 27.8 & 72.2 \\
\hline Used carpooling & 30.4 & 69.6 \\
\hline Purchased environmentally friendly products & 45.8 & 54.2 \\
\hline Did any form of voluntary work in your community & 19.8 & 80.2 \\
\hline Donated money to charities & 49.8 & 50.2 \\
\hline Refused to take a plastic bag from the supermarket & 12.3 & 87.7 \\
\hline Used energy saving light bulbs & 67 & 33 \\
\hline
\end{tabular}

Cross tabulations and Pearson's chi-square results show that some actions are dependent on gender, mainly purchasing eco-labelled and fair-trade products, donating money to charities, refusing to take a plastic bag from the supermarket and using energy saving light bulbs with male students stating that they performed more of these actions for SD reasons (Table 4).

Table 4. Chi-square test for the different SD-related actions across gender

\begin{tabular}{|c|c|c|c|c|c|c|c|}
\hline \multirow{3}{*}{ SD-related actions } & & \multicolumn{4}{|c|}{ Gender } & \multicolumn{2}{|c|}{$\mathrm{X}^{2}$-test } \\
\hline & & \multicolumn{2}{|c|}{ Female } & \multicolumn{2}{|c|}{ Male } & \multirow{2}{*}{$\begin{array}{l}\text { Fisher's } \\
\text { exact test }\end{array}$} & \multirow[b]{2}{*}{$\begin{array}{c}\text { Signifi- } \\
\text { cance }\end{array}$} \\
\hline & & Count & $\begin{array}{l}\% \text { of } \\
\text { total }\end{array}$ & Count & $\begin{array}{l}\% \text { of } \\
\text { total }\end{array}$ & & \\
\hline 1 & 2 & 3 & 4 & 5 & 6 & 7 & 8 \\
\hline \multirow{2}{*}{$\begin{array}{l}\text { Switched off unnecessary } \\
\text { lights }\end{array}$} & No & 24 & 10.7 & 33 & 14.7 & \multirow{2}{*}{0.220} & \multirow{2}{*}{0.110} \\
\hline & Yes & 88 & 39.3 & 79 & 35.3 & & \\
\hline \multirow{2}{*}{$\begin{array}{l}\text { Purchased eco-labelled and } \\
\text { fair-trade products }\end{array}$} & No & 92 & 41.1 & 77 & 34.4 & \multirow{2}{*}{0.029} & \multirow{2}{*}{$0.015 *$} \\
\hline & Yes & 20 & 8.9 & 35 & 15.6 & & \\
\hline
\end{tabular}


Sequel to Table 4.

\begin{tabular}{|c|c|c|c|c|c|c|c|}
\hline 1 & 2 & 3 & 4 & 5 & 6 & 7 & 8 \\
\hline \multirow{2}{*}{$\begin{array}{l}\text { Recycled cans, glass or } \\
\text { paper }\end{array}$} & No & 85 & 37.9 & 77 & 34.4 & \multirow{2}{*}{0.296} & \multirow{2}{*}{0.148} \\
\hline & Yes & 27 & 12.1 & 35 & 15.6 & & \\
\hline \multirow[t]{2}{*}{ Used carpooling } & No & 81 & 36.2 & 74 & 33.0 & \multirow{2}{*}{0.385} & \multirow{2}{*}{0.193} \\
\hline & Yes & 31 & 13.8 & 38 & 17.0 & & \\
\hline \multirow{2}{*}{$\begin{array}{l}\text { Purchased environmentally } \\
\text { friendly products }\end{array}$} & No & 61 & 27.2 & 62 & 27.7 & \multirow{2}{*}{1.00} & \multirow{2}{*}{0.50} \\
\hline & Yes & 51 & 22.8 & 50 & 22.3 & & \\
\hline \multirow{2}{*}{$\begin{array}{l}\text { Did any form of voluntary } \\
\text { work in your community }\end{array}$} & No & 93 & 41.5 & 87 & 38.8 & \multirow{2}{*}{0.401} & \multirow{2}{*}{0.20} \\
\hline & Yes & 19 & 8.5 & 25 & 11.2 & & \\
\hline \multirow[t]{2}{*}{ Donated money to charities } & No & 64 & 28.6 & 49 & 21.9 & \multirow{2}{*}{0.061} & \multirow{2}{*}{$0.031 *$} \\
\hline & Yes & 48 & 21.4 & 63 & 28.1 & & \\
\hline \multirow{2}{*}{$\begin{array}{l}\text { Refused to take a plastic bag } \\
\text { from the supermarket }\end{array}$} & No & 104 & 46.4 & 92 & 41.1 & \multirow{2}{*}{0.025} & \multirow{2}{*}{$0.012 *$} \\
\hline & Yes & 8 & 7.1 & 20 & 8.9 & & \\
\hline \multirow{2}{*}{$\begin{array}{l}\text { Used energy saving light } \\
\text { bulbs }\end{array}$} & No & 43 & 19.2 & 31 & 13.8 & \multirow{2}{*}{0.118} & \multirow{2}{*}{$0.059 *$} \\
\hline & Yes & 69 & 30.8 & 81 & 36.2 & & \\
\hline
\end{tabular}

\section{Teaching and learning methods}

The questionnaire included a list of ten teaching and learning methods, and students were asked to rank them according to their frequency of use at the university. From their responses summarised in Table 5, lecturing came in first at $66.1 \%$, interactive engagement came in second at $29.5 \%$, project-based learning was in the third place at $20.7 \%$. A careful examination of the percentages shows some kind of competition over the ranks given by the students to the other various methods. This could be due to the fact that students are not familiar with those methods, such as inquiry-based, casebased instruction, interdisciplinary teaching, problem-based learning, tech-supported instruction, placed-based learning and discovery learning. This result was expected, and this is why an explanation of the different methods was provided to the students; however, the analysis still shows mixed results about the ranks.

Table 5. Teaching and learning methods used in the courses

\begin{tabular}{|c|c|c|c|c|c|c|c|c|c|c|c|}
\hline $\begin{array}{l}\text { Teaching and learning } \\
\text { methods }\end{array}$ & 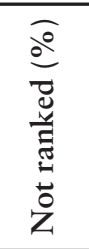 & 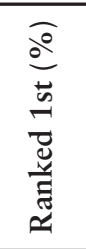 & 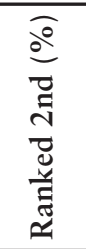 & 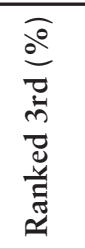 & 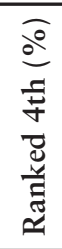 & 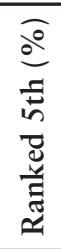 & 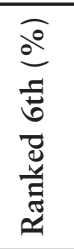 & 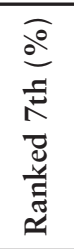 & 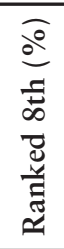 & 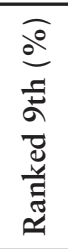 & 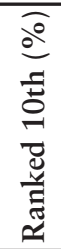 \\
\hline 1 & 2 & 3 & 4 & 5 & 6 & 7 & 8 & 9 & 10 & 11 & 12 \\
\hline Lecturing & 5.7 & 66.1 & 12.3 & 8.8 & 2.2 & 0.4 & 0.4 & 1.8 & 0.4 & & 1.8 \\
\hline Project-based learning & 13.2 & 25.1 & 26.4 & 20.7 & 7.5 & 2.2 & 3.1 & 0.9 & 0.9 & & \\
\hline Interactive engagement & 22.0 & 13.2 & 29.5 & 15.0 & 6.6 & 7.5 & 2.2 & 1.3 & 2.2 & 0.4 & \\
\hline Case-based instruction & 15.9 & 18.9 & 26.0 & 16.3 & 7.0 & 6.2 & 2.6 & 2.6 & 1.3 & 2.2 & 0.9 \\
\hline
\end{tabular}


Sequel to Table 5.

\begin{tabular}{lccccccccccc}
\hline \multicolumn{1}{c}{1} & $\mathbf{2}$ & $\mathbf{3}$ & 4 & $\mathbf{5}$ & $\mathbf{6}$ & $\mathbf{7}$ & $\mathbf{8}$ & $\mathbf{9}$ & $\mathbf{1 0}$ & $\mathbf{1 1}$ & $\mathbf{1 2}$ \\
\hline Inquiry-based learning & 24.2 & 14.1 & 18.1 & 16.3 & 7.5 & 6.6 & 4.0 & 3.1 & 3.5 & 1.8 & 0.9 \\
\hline Interdisciplinary teaching & 31.7 & 9.7 & 17.6 & 12.3 & 3.5 & 4.0 & 6.6 & 5.3 & 4.4 & 1.8 & 3.1 \\
\hline Problem-based learning & 21.6 & 12.3 & 19.4 & 17.6 & 7.0 & 4.0 & 5.7 & 6.6 & 2.6 & 1.3 & 1.8 \\
\hline Tech-supported instruction & 29.5 & 10.6 & 15.4 & 13.7 & 3.5 & 4.0 & 5.3 & 5.3 & 7.5 & 4.4 & 0.9 \\
\hline Placed-based learning & 36.1 & 6.2 & 8.4 & 17.2 & 3.1 & 4.4 & 2.2 & 1.8 & 4.0 & 9.3 & 7.5 \\
\hline Discovery learning & 33.0 & 7.5 & 7.0 & 20.7 & 3.5 & 4.0 & 3.5 & 0.9 & 2.6 & 7.0 & 10.1 \\
\hline
\end{tabular}

Table 6 suggests that the top three teaching and learning methods listed according to those ranked in first position as the most widely used are: lecturing $(66.1 \%$ of the students ranked it number one), project-based learning (25.1\% ranked it number one) and case-based instruction (18.9\% ranked it number one). When asked about the second rank, the order of these top three teaching and learning methods has changed; projectbased learning is the first, followed by case-based instruction and then lecturing. The third rank places project-based learning first, followed by case-based instruction and then lecturing.

Table 6. The top three teaching and learning methods according to rank one as shown in Table 5

\begin{tabular}{lcccccc}
\hline \multirow{2}{*}{$\begin{array}{c}\text { Teaching and learning } \\
\text { methods }\end{array}$} & \multicolumn{2}{c}{ Rank 1 } & \multicolumn{2}{c}{ Rank 2 } & \multicolumn{2}{c}{ Rank 3 } \\
\cline { 2 - 7 } & $\mathbf{N}$ & $\mathbf{\%}$ & $\mathbf{N}$ & $\mathbf{\%}$ & $\mathbf{N}$ & \% \\
\hline Lecturing & 150 & 66.1 & 28 & 12.3 & 20 & 8.8 \\
\hline Project-based learning & 57 & 25.1 & 60 & 26.4 & 47 & 20.7 \\
\hline Case-based instruction & 43 & 18.9 & 59 & 26.0 & 37 & 16.3 \\
\hline
\end{tabular}

To enhance learning about SD issues, different teaching methodologies should be used in the classroom, which does not seem to be the case in the present study. The majority of the students indicated that lecturing is the most used teaching method. Lecturing is definitely most helpful to disseminate information quickly to a large audience. However, it should be combined with other teaching methods in order to facilitate students' involvement, develop analytical, collaborative and communication skills and encourage critical thinking - all needed in ESD.

\section{Preferred function of education}

Students were asked about the four functions of education they prefer most. Nobody responded 'to replicate the existing society and culture', $24.2 \%$ selected 'to train people for future employment', $41.4 \%$ answered 'to help people develop their potential', and $33 \%$ chose 'to encourage change towards a fairer society and a better world'. Three respondents did not answer the question. Chi-square test showed no significant difference between males' and females' responses on that particular question.

These results are interesting in that not one student responded 'to replicate the existing society and culture'. This is a remarkable finding proving that the students are conscious of the necessity to transform and change the existing society. Students mostly prefer that education plays a role in helping people to develop their potential, followed by encouraging change towards a fairer society and a better world. 


\section{ESD attitudes}

Students' ESD attitudes were assessed through a series of 10 items in the survey (Table $7)$. The majority of the respondents $(81.5 \%)$ agree that people should be prepared to make sacrifices to improve the quality of life for others. Also, $76.2 \%$ agree that everyone should look after themselves rather than rely on the government for help. The answers revealed that a large percentage of the students $(59.9 \%)$ disagree with the statement: There is little connection between the protection of the environment and people's quality of life. Despite the recent global financial and economic crisis and the high level of unemployment, 66.1\% disagree with the statement: Economic growth and increased employment are more important than protecting the environment.

Table 7. Students' attitudes towards ESD

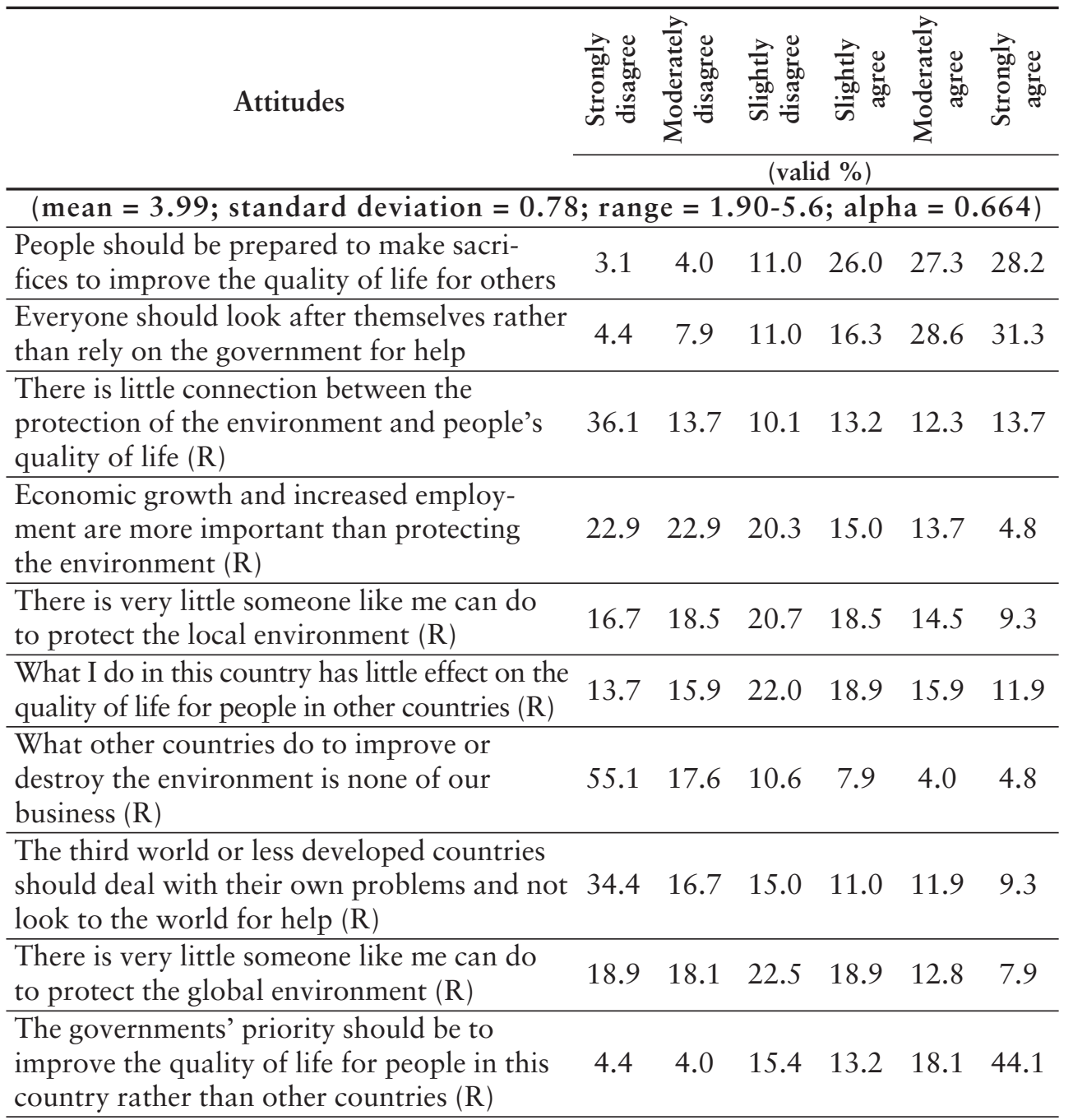

The negative and positive poles of the scale are: 'strongly disagree' and 'strongly agree' $(\mathrm{R})$ : reversed score 
A relatively high percentage $(42.3 \%)$ agrees with the statement: There is very little someone like me can do to protect the local environment. Also, $39.6 \%$ of the students agree with the statement: There is very little someone like me can do to protect the global environment. Only $51.6 \%$ disagree with the statement: What I do in this country has little effect on the quality of life for people in other countries. The results show that a relatively high number of students are not aware of their personal responsibilities towards local and global environmental problems. The majority (83.3\%) disagree with the statement: What other countries do to improve or destroy the environment is none of our business. In addition, $75.4 \%$ agree with the statement: The government's priority should be to improve the quality of life for people in this country rather than other countries. And, $66.1 \%$ disagree with the statement: The third world or less developed countries should deal with their own problems and not look to the world for help. The majority $(75.4 \%)$ do care for the improvement of the quality of life in their country and do not care for other countries. These findings suggest the need for a revised curriculum, a more effective education process where courses are restructured to inform students of their responsibility towards the environment and the quality of life of individuals in other countries.

The mean score for the attitudes items was computed. It was found to be 3.924 for the study sample. A one-way ANOVA was conducted to check if there is a difference between female and male students in their ESD attitudes. P-value was found to be $0.017(<0.05)$ suggesting that there is a significant statistical difference between the mean attitudes across gender. It is important to note that the higher mean score indicates more pro-environmental attitudes. The female students are found to have a higher mean attitude (4.0175; $\mathrm{SD}=0.5841)$ compared to male students $(3.8284 ; \mathrm{SD}=0.5913)$. While only $5.3 \%$ of the sample show mean attitude less than $3 ; 94.7 \%$ scored 3 or greater. It was found that $50.2 \%$ of the sample show mean ESD attitudes less than 4 , and $49.8 \%$ had mean ESD attitudes at 4 or greater than 4 .

\section{ESD competences}

Students were asked about their general and disciplinary ESD competences. The survey included twelve items for each of the clusters learning to be and learning to do. Also, it comprised ten items to assess each of the learning to live sustainably, learning to know and learning to transform clusters. As for the disciplinary competences, they were assessed by 18 items. The mean score was computed for the different five pillars of learning items, in addition to the disciplinary business competences. The competence clusters were categorised in such a way that those who have a mean competence greater or equal to three are considered to have 'good' ESD competences in the different clusters. It was found that $98.7 \%$ of the total sample of the students show learning to be competences $\geq 3 ; 97.3 \%$ show learning to live sustainably competences $\geq 3 ; 97.4 \%$ show learning to know competences $\geq 3 ; 97.8 \%$ show learning to do competences $\geq 3 ; 99.1 \%$ show learning to transform competences $\geq 3$. As for disciplinary competences, $97.3 \%$ show business competences $\geq 3$. This classification of competences was not very insightful. Another way to classify competences was computed such that mean competences less than two are considered as 'poor', those between two and 3.99 are considered as 'good', and those between four and six are considered as 'very good' (Table 8). Of the total sample of students, only one student $(0.4 \%)$ showed 'poor' learning to do competences. The majority of the students show 'very good' competences with $82.4 \%$ for the learning 
to be cluster, followed by $75.8 \%$ for learning to know, $74.8 \%$ for learning to transform, $74 \%$ for learning to do and $72.1 \%$ for learning to live sustainably. For the disciplinary competences, $68 \%$ showed 'very good' competences suggesting that more efforts need to be done to enhance business competences.

Table 8. Mean ESD competences

\begin{tabular}{|c|c|c|c|c|c|c|}
\hline $\begin{array}{c}\text { Mean competence } \\
(\text { valid \%) }\end{array}$ & 先 & 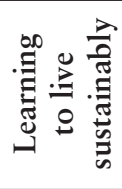 & 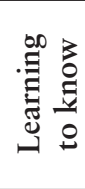 & 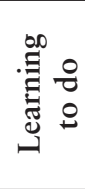 & 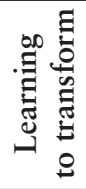 & 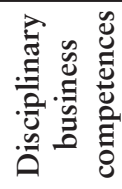 \\
\hline From 0 to 1.99 (poor) & - & - & - & 0.4 & - & - \\
\hline From 2 to 3.99 (good) & 17.6 & 27.9 & 24.2 & 25.6 & 25.2 & 32.0 \\
\hline From 4 to 6 (very good) & 82.4 & 72.1 & 75.8 & 74.0 & 74.8 & 68.0 \\
\hline
\end{tabular}

A one-way ANOVA was conducted to check if there is a difference between female and male students in their ESD competences. The means for the two gender groups are displayed in Table 9. ANOVA did not show any statistical difference between the two gender groups on the five general pillars of learning. However, P-value was found to be $0.005(<0.05)$ for the disciplinary business competences suggesting that there is a significant statistical difference between the mean disciplinary competences across gender. The female students have a lower mean business competences $(4.21 ; \mathrm{SD}=0.78)$ than male students $(4.49 ; \mathrm{SD}=0.72)$.

Table 9. Cross tabulations of competences across gender

\begin{tabular}{|c|c|c|c|c|c|c|c|}
\hline Gender & & 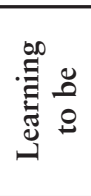 & 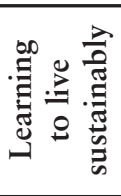 & 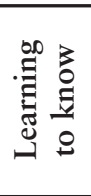 & 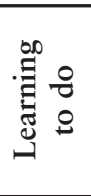 & 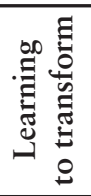 & 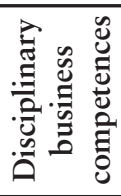 \\
\hline \multirow{3}{*}{ Female } & Mean & 4.60 & 4.42 & 4.44 & 4.41 & 4.57 & $4.21^{*}$ \\
\hline & $\mathrm{n}$ & 112 & 111 & 112 & 112 & 111 & 110 \\
\hline & SD & 0.75 & 0.78 & 0.77 & 0.80 & 0.82 & 0.78 \\
\hline \multirow{3}{*}{ Male } & Mean & 4.61 & 4.46 & 4.48 & 4.53 & 4.55 & $4.49 *$ \\
\hline & $\mathrm{n}$ & 112 & 112 & 112 & 112 & 112 & 112 \\
\hline & SD & 0.71 & 0.75 & 0.76 & 0.71 & 0.72 & 0.72 \\
\hline \multirow{3}{*}{ Total } & Mean & 4.60 & 4.44 & 4.46 & 4.47 & 4.55 & 4.35 \\
\hline & $\mathrm{n}$ & 224 & 223 & 224 & 224 & 223 & 222 \\
\hline & SD & 0.73 & 0.76 & 0.76 & 0.76 & 0.77 & 0.76 \\
\hline
\end{tabular}

Finally, among the competence clusters, a paired t-test was performed to find the mean differences of the different competence clusters (Table 10). Results of the paired t-test for the different competence clusters suggest the following significant statistical mean differences:

a) learning to live sustainably $(4.44)<$ learning to be $(4.60)$;

b) learning to know $(4.46)<$ learning to be $(4.60)$; 
c) learning to do $(4.47)<$ learning to be $(4.60)$;

d) learning to live sustainably $(4.44)<$ learning to transform (4.55);

e) learning to know (4.46) < learning to transform (4.55);

f) learning to do $(4.47)<$ learning to transform (4.55).

There is no statistical difference between the means for:

g) learning to know and learning to live sustainably;

h) learning to do and learning to live sustainably;

i) learning to do and learning to know;

j) learning to be and learning to transform.

As for the disciplinary competences, $t$-tests show clearly that the disciplinary competences are significantly lower than the five pillars of learning, which suggest that the FBAE at NDU needs to emphasise the disciplinary ESD competences in its curricula.

Table 10. Paired t-test among the competence clusters

\begin{tabular}{|c|c|c|c|c|c|}
\hline $\begin{array}{l}\text { Competence } \\
\text { (mean, standard deviation) }\end{array}$ & 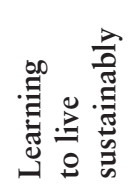 & 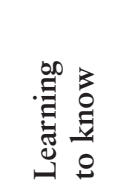 & 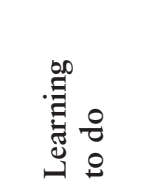 & 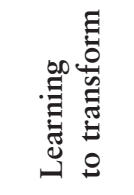 & 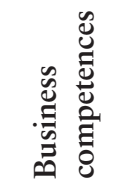 \\
\hline $\begin{array}{l}\text { Learning to be } \\
(4.60 ; 0.73)\end{array}$ & $\begin{array}{c}4.731 \\
(0.000) * \\
\end{array}$ & $\begin{array}{c}3.721 \\
(0.000) *\end{array}$ & $\begin{array}{c}3.577 \\
(0.000) *\end{array}$ & $\begin{array}{c}1.052 \\
(0.294)\end{array}$ & $\begin{array}{c}5.696 \\
(0.000) *\end{array}$ \\
\hline $\begin{array}{l}\text { Learning to live sustainably } \\
(4.44 ; 0.76)\end{array}$ & -0.519 & $\begin{array}{l}-0.706 \\
(0.605)\end{array}$ & $\begin{array}{l}-2.609 \\
(0.481)\end{array}$ & $\begin{array}{c}1.955 \\
(0.010) *\end{array}$ & $(0.052)^{*}$ \\
\hline $\begin{array}{l}\text { Learning to know } \\
(4.46 ; 0.76)\end{array}$ & & & $\begin{array}{l}-0.220 \\
(0.826)\end{array}$ & $\begin{array}{c}-2.260 \\
(0.025)^{*}\end{array}$ & $\begin{array}{c}2.932 \\
(0.004) *\end{array}$ \\
\hline $\begin{array}{l}\text { Learning to do } \\
(4.47 ; 0.76)\end{array}$ & & & & $\begin{array}{c}-2.107 \\
(0.036) *\end{array}$ & $\begin{array}{c}3.119 \\
(0.002) *\end{array}$ \\
\hline $\begin{array}{l}\text { Learning to transform } \\
(4.55 ; 0.77)\end{array}$ & & & & & $\begin{array}{c}5.279 \\
(0.000)^{*}\end{array}$ \\
\hline $\begin{array}{l}\text { Business competences } \\
(4.35 ; 0.76)\end{array}$ & & & & & \\
\hline
\end{tabular}

\section{Implications for ESD teaching and learning methods}

The analysis of the teaching and learning methods used at the university seems to imply that only few methods are used; namely, lecturing, project-based learning and casebased instruction. It is important to use various teaching methodologies in classrooms in order to improve learning about SD issues. The evolution to hybrid forms of teaching methodologies renders teaching compatible to the ESD objectives and principles. It is true that lecturing is most appropriate and efficient when introducing large numbers of students to a particular field of study. It gives students the information not elsewhere available; it summarises, synthesises and organises for the students the content of numerous articles and books helping them to learn by listening to the ideas of others; it allows sharing of information, the logical succession of ideas and eventually promotes the formulation of solutions (Kam-Fai, 1973). However, in order to infuse ESD more efficiently, other teaching and learning methods need to be enhanced in universities. 
Project-based learning, for instance, is crucial to address complex SD topics as it is a student-centred experiential learning approach by nature. This method requires the learners' initiatives and independent investigation, it can also involve the local community and mobilise its resources (Frey, 1986; Scoullos \& Malotidi, 2004). Case-based instruction is an active, learner-centred model that is used to facilitate the development of reasoning skills and to connect classroom teaching to real world scenarios. This method can be used to teach content, engage students with factual data and provide opportunities for learners to position themselves in professional decision-making situations. Through this process, they develop analytical, collaborative and communication skills (Hartfield, 2010). Inquiry-based learning offers many opportunities to examine the complexity of SD issues. This method stimulates students' curiosity and encourages them to actively explore and seek out new evidence to support their own response to the problem (Kahn \& O’Rourke, 2005).

As the nexus between society and environment becomes more apparent, so the notion of integration across disciplines becomes essential. Interdisciplinary learning methods help students collaborate with other professions that 'see' things from a different perspective. Many reports indicate that these methods are necessary to approach the most critical current global challenges; including climate change, sustainability, energy and public health (Borrego \& Newswander, 2010). Interdisciplinary learning methods require cooperative learning and are based on the principles of constructivism and experiential learning, by which learners experience working across many disciplines and construct new ideas and concepts. These methods greatly promote many of the core ESD principles as they advocate pluralism of ideas and methods and bring learners out of the 'box' of their discipline to develop an appreciation for diverse ways of thinking.

As for problem-based learning, it is used to engage students in becoming active in the learning process. It is characterised by learning via contextualised problem-setting based on real conditions. Complex problems from the real world are used as a stimulus for learning and developing personal competences (Scoullos \& Malotidi, 2004). Information and communication technologies (ICTs) or tech-supported instruction encompasses a very large spectrum of information handling tools, including traditional tools like radio, television and telephone up to the most sophisticated satellite, internet and wireless technologies (Reddi, 2004). ICT-enabled learning brings about implications within the ESD framework with regards to the shift from a teacher-centred approach to a learner-centred approach. E-learning brings about the appreciation of multi-disciplinarity and of cross-fertilisation between different disciplines and technological know-how.

Placed-based or service-learning integrates meaningful community service with instruction and reflection to enrich the learning experience, teach civic responsibility and strengthen communities (Seifer \& Connors, 2007). While servicing their communities, students increase their academic achievement, apply scientific knowledge, develop communication skills, foster social responsibility attitudes and develop active citizenship in areas such as public safety and the environment. Service-learning method is a transformative process as it can provide students with 'transformational learning experiences'. The integration of ESD techniques in service learning is a common practice within formal education.

Discovery learning involves an instructional model that focuses on active, handson learning opportunities for students (Dewey, 1916/1997; Piaget, 1954, 1973). With discovery learning, students are actively seeking new knowledge and are engaged in prac- 
tical activities that are real problems requiring solutions. This method motivates learners and allows them to seek information that satisfies their natural curiosity (Castronova, 2002). Bicknell-Holmes \& Hoffman (2000) describe three main characteristics of discovery learning as 1) exploring and problem solving to create, integrate and generalise knowledge; 2) encouraging students to learn at their own pace and 3) integrating new knowledge into the learner's existing knowledge base. Discovery learning allows students to interact with their environment by manipulating objects and wrestling with controversies. ESD aims at developing meta-cognitive skills and motivation which are main principles of discovery learning strategy. Applying discovery learning substantially promotes ESD.

\section{Conclusion}

The study results indicate that the research participants, FBAE students at NDU, consider the internet as the most used source of information about SD. University courses were ranked second with only $30 \%$ of the students giving them this rank. Only $22.5 \%$ of surveyed students gave the university courses the first rank as a source of information about SD issues. If we acknowledge that HEIs are among the key institutions that can contribute to proposing solutions for sustainability issues (Saadatian, Binti Dola, Salleh, \& Mohd Tahir, 2011), the findings of this study suggest a real need to reorient university curricula to improve ESD, so that courses featuring the development of sustainability skills are seen as providing information for students, rather than as a redundant fashionable option.

The findings of this study suggest that students do not perform actions for SD reasons. Male students are more likely 'to do' SD-related actions than female students. In making SD a reality, it is essential 'to do' actions related to sustainability. Reinforcing knowledge about SD is important in education; however, it is also important to help students move from 'knowing' to 'doing'. One of the learning pillars, learning to do, focuses on the ability of the learner to put what is learned into practice. It is about knowing how to act for active and responsible engagement in order to take actions related to global and local SD issues. Reorienting existing university curricula to address ESD, emphasising the five learning pillars, is necessary to equip graduates with knowledge, skills, perspectives and values of sustainability and to assume responsibility for creating a sustainable future. By integrating sustainability into major activities of educational institutions, universities can help prepare students to take actions to face the complex, dynamic and uncertain future. New curricula need to promote a sense of both local and global responsibility so that students reflect on new lifestyles (new actions) which combine well-being, quality of life and respect for nature and other people.

The analysis of the ESD attitudes shows a mean attitude of 3.924 for the study sample with the female students having a slightly higher mean attitude than male students. The attitudes mean ranges from 2.4 to 5.3. If we consider those who have an attitude mean of 4 to have favourable ESD attitudes, we can conclude that about half of the sample $(50.2 \%)$ shows mean ESD attitudes less than 4 , and $49.8 \%$ had mean ESD attitudes at 4 or greater than 4 . Additionally, the results show that a relatively high number of students are not aware of their personal responsibilities towards local and global environmental problems. These findings suggest the need for a revised curriculum to address sustainability, a more effective education process where courses are restructured to infuse ESD and enhance students' responsibility towards their environment and the quality of life of individuals in their local communities as well as in other countries. 
The analysis of the general competences reveals that the majority of the students show 'very good' competences ranging from $72.1 \%$ for learning to live sustainably to $82.4 \%$ for the learning to be cluster. The results of the paired t-test for the different competence clusters suggest that learning to live together sustainably has the lowest mean and learning to be has the highest mean. Revised curricula are needed to enhance the learning to live together sustainably competences. This pillar highlights the interdisciplinary nature of ESD. It addresses the critical skills that are essential for a better life where all have equal opportunities to develop themselves and to contribute to their well-being. As for the disciplinary competences, $68 \%$ of the sample showed 'very good' competences suggesting that more work needs to be done to enhance disciplinary competences. The results of ANOVA show that female students have a lower mean for the business competences than male students. Additionally, t-tests show that the disciplinary competences are significantly lower than the five pillars of learning. We acknowledged earlier that students and academicians are or will be the future leaders of the society. If we admit that business schools are responsible to prepare students for careers tailored towards a greener economy, business schools need to reorient their curricula to infuse ESD into their programmes through the development of effective pedagogical approaches and learning materials.

Generally, the results obtained from this study suggest that it is time that Arab countries realise the profound association between the environment and development. The many environmental challenges in Arab countries can well put this region of the world beyond its resource limits, threatening its long-term ability to support life and contributing to increasing human vulnerability. It is important for governments in the Arab region to develop national educational strategies for SD to help new generations face the complexities of the global challenges. "Education for sustainable development is not an option but a priority" (UNESCO, 2005, p. 4). ESD is transformative education at heart, and it aims to influence education towards effectively addressing global challenges. ESD has many drives including empowering learners to realise their individual potential as well as contributing to social transformation. Education is asked to create a balance between environmental, societal, cultural and economic considerations in order to ensure a better quality of life. The UN system sees an alternative future out of the crisis in terms of a 'green economy' with ESD as the best educational framework for addressing global problems (Von der Heidt \& Lamberton, 2011). The Interagency Statement of the United Nations system of 25 June 2009 entitled "Green Economy: A Transformation to Address Multiple Crises" clearly states that "the shift towards a green economy requires education for sustainable development” (UNESCO, 2010, p. 2). Creating green economies and sustainable societies requires more than technological advancements, it necessitates a transformation in attitudes, competences and behaviours to prepare younger generations for a sustainable future.

Humans will not be able to solve today's problems with the same approaches that created them. Einstein argued that we cannot resolve problems from within the same mindset that created them (Irwin, 2012). What kind of future should education prepare learners for? ESD has a lot to contribute answering this question. The results of this study are insightful in that when asked about the function of education that students prefer, no one answered 'to replicate the existing society and culture'. The most selected students' responses to this question went for 'to help people develop their potential' and 'to encourage change towards a fairer society and a better world'. This is an interesting 
implication confirming that students are aware of the need for a change, for a societal transformation in our world. In order to achieve this, we need to put the world on a more SD-oriented path. A holistic and ecological worldview is needed to create sustainable solutions. Expanding information, expanding involvement: these are keys to comprehend the complexity of this world and to 'change'. Working together, as educators, governments, businesses and citizens, we can deepen our understanding of sustainability issues and enable the present generations to participate in passing along a safe, healthy world to our children and grandchildren.

\section{Acknowledgement}

This work has been developed within the framework of the RUCAS (Reorient University Curricula to Address Sustainability) project that has been funded from the European Commission (European Commission, TEMPUS - No. 511118-2010-GR-JPCR). The content of the paper reflects the views of the author, and the Commission cannot be held responsible for any use which may be made of the information contained therein.

\section{References:}

Abahussain, A. A., Abdu, A. S., Al-Zubari, W. K., El-Deen, N. A., \& Abdul-Raheem, M. (2002). Desertification in the Arab region: Analysis of current status and trends. Journal of Arid Environments, 51(4), 521-545.

Arab Climate Resilience Initiative. (2010). Regional consultation in Syria-water scarcity, drought and population mobility. Retrieved December 15, 2012, from http://www. arabclimateinitiative.org/water-scarcity-drought-and-desertification.html

AFED (Arab Forum for Environment and Development). (2011). Green economy in a changing Arab world. Retrieved December 17, 2012, from http://afedonline.org/ Report2011/PDF/En/intro.pdf

Bicknell-Holmes, T., \& Hoffman, P. S. (2000). Elicit, engage, experience, explore: Discovery learning in library instruction. Reference Services Review, 28(4), 313-322.

Borrego, M., \& Newswander, L. K. (2010). Definitions of interdisciplinary research: Toward graduate-level interdisciplinary learning outcomes. The Review of Higher Education, 34(1), 61-84.

Castronova, J. A. (2002). Discovery learning for the 21st century: What is it and how does it compare to traditional learning in effectiveness in the 21st century? Action Research Exchange, 1(1). Retrieved December 17, 2012, from http://chiron.valdosta. edu/are/Litreviews/vol1no1/castronova_litr.pdf

Costanza, R. (2011a, October). Needed: The solutions generation. The Solutions Journal, 3(1). Retrieved December 17, 2012, from http://www.thesolutionsjournal.com/node/ 991

Costanza, R. (2011b, November). Changing the way we view humanity and the rest of nature. The Solutions Journal, 2(6). Retrieved December 17, 2012, from http://www. thesolutionsjournal.com/node/1010

Delors, J. (1996). Learning: The treasure within. Retrieved December 17, 2012, from http://www.unesco.org/delors/delors_e.pdf

Dewey, J. (1997). Democracy and education. New York: Simon and Schuster. 
ESCWA (Economic and Social Commission for Western Asia). (2010). The third Arab report on the Millennium Development Goals 2010 and the impact on the global economic crises. Retrieved December 17, 2012, from the ESCWA website http://www. escwa.un.org/information/publications/edit/upload/EDGD-10-3.pdf

Frey, K. (1986). The project method. Thessaloniki: Kyriakidis.

Hartfield, P. J. (2010). Reinforcing constructivist teaching in advanced level biochemistry through the introduction of case-based learning activities. Journal of Learning Design, 3(3), 20-31.

IPCC (Intergovernmental Panel on Climate change). (2007). Synthesis report. Retrieved December 17, 2012, from http:/www.ipcc.ch/pdf/assessment-report/ar4/syr/ ar4_syr.pdf

Irwin, T. (2012, April). Transforming the design process to create better solutions. The Solutions Journal, 3(2). Retrieved December 17, 2012, from http://www.thesolutions journal.com/node/1084

Kahn, P., \& O’Rourke, K. (2005). Understanding enquiry based learning. In T. Barrett, I. Mac Labhrainn \& H. Fallon (Eds.), Handbook of enquiry \& problem-based learning: Irish case studies and international perspectives (pp. 1-12). Retrieved December 15, 2012, from http://www.aishe.org/readings/2005-2/chapter1.pdf

Kam-Fai, H. (1973). Preferred teaching method: Lecture, discussion or tutorial? Studium, 4, 153-165.

Kanbar, N. (in press). Overview of Arab region ecosystems. Arab millennium ecosystem assessment. Nairobi: UNEP (United Nations Environment Program).

Kemp, R., Parto, S., \& Gibson, R. B. (2005). Governance for sustainable development: Moving from theory to practice. International Journal of Sustainable Development, $8(1-2), 12-30$.

Lubin, D. A., \& Esty, D. C. (2010). The sustainability imperative. Harvard Business Review, 88(5), 43-50.

Makrakis, V., Kostoulas-Makrakis, N., \& Kanbar, N. (2012). Developing and validating an ESD student competence framework: A Tempus-RUCAS Initiative. In S. A. Anwar (Ed.), Proceedings of the 5th Conference on eLearning Excellence in the Middle East-Sustainable Innovation in Education (pp. 585-594). Dubai, UAE: Hamdan Bin Mohammed e-University.

Munier, N. (2005). Introduction to sustainability: Road to a better future. Dordrecht, NL: Springer.

Piaget, J. (1954). Construction of reality in the child. New York: Basic Books.

Piaget, J. (1973). To understand is to invent. New York: Grossman.

Reddi, U. V. (2004). Role of ICTS in education and development: Potential pitfalls and challenges. Retrieved December 17, 2012, from http://www.unesco.org/education/ aladin/paldin/pdf/course01/unit_13.pdf

Saadatian, O., Binti Dola, K., Salleh, E., \& Tahir, O. (2011). Identifying strength and weakness of sustainable higher educational assessment approaches. International Journal of Business and Social Science, 2(3), 137-146.

Schmuck, P., \& Schultz, W. P. (2002). Psychology of sustainable development. Norwell, MA: Kluwer Academic Publishers.

Scoullos, M., \& Malotidi, V. (2004). Handbook on methods used in environmental education and education for sustainable development. Athens: MIO-ECSDE.

Seifer, S. D., \& Connors, K. (Eds.). (2007). Faculty toolkit for service-learning in higher education. Scotts Valley, CA: National Service-Learning Clearinghouse. 
Spiropoulou, D., Antonakaki, T., Kontaxaki, S., \& Bouras, S. (2007). Primary teachers' literacy and attitudes on education for sustainable development. Journal of Science Education and Technology, 16(5), 443-450.

UN (United Nations). (1992). Agenda 21, Chapter 36: Promoting education, public awareness and training. Retrieved December 3, 2012, from http://www.undocuments. net/a21-36.htm

UNDP (United Nations Development Programme). (2009). Arab human development report 2009: Challenges to human security in the Arab countries. Retrieved December 17, 2012, from http:/www.arab-hdr.org/publications/other/ahdr/ahdr2009e.pdf

UNESCO (United Nations Educational, Scientific and Cultural Organization). (1978). Intergovernmental conference on environmental education. Retrieved December 3, 2012, from http://unesdoc.unesco.org/images/0003/000327/032763eo.pdf

UNESCO (United Nations Educational, Scientific and Cultural Organization). (2005). UN Decade of Education for Sustainable Development 2005-2014: The DESD at a glance. Retrieved December 3, 2012, from http://unesdoc.unesco.org/images/0014/ 001416/141629e.pdf

UNESCO (United Nations Educational, Scientific and Cultural Organization). (2007). The UN Decade of Education for Sustainable Development (DESD 2005-2014): The first two years. Retrieved December 3, 2012, from http://unesdoc.unesco.org/ images/0015/001540/154093e.pdf

UNESCO (United Nations Educational, Scientific and Cultural Organization). (2009). UNESCO world conference on education for sustainable development. Retrieved December 3, 2012, from http://www.esd-world-conference-2009.org/fileadmin/ download/ESD2009_BonnDeclaration080409.pdf

UNESCO (United Nations Educational, Scientific and Cultural Organization). (2010). Implementation of the United Nations Decade of Education for Sustainable Development (2005-2014). Adoption and implementation of the UNESCO strategy for the second half of the decade. Retrieved December 3, 2012, from http://unesdoc. unesco. org/images/0018/001891/189145e.pdf

UNESCO (United Nations Educational, Scientific and Cultural Organization). (n.d.). ESD and other types of educations. Retrieved December 2, 2012, from http://www. unesco.org/new/en/education/themes/leading-the-international-agenda/educationfor-sustainable-development/education-for-sustainable-development/esd-and-othertypes-of-educations/

Von Der Heidt, T., \& Lamberton, G. (2011). Sustainability in the undergraduate and postgraduate business curriculum of a regional university: A critical perspective. Journal of Management \&o Organization, 17, 670-690.

World Bank. (2012). Toward a green, clean, and resilient world for all: A World Bank Group environment strategy 2012-2022. Retrieved December 3, 2012, from http://siteresources.worldbank.org/ENVIRONMENT/Resources/Env_Stratgy_ 2012.pdf

\section{Correspondence:}

Dr Nancy Kanbar, Faculty of Business Administration and Economics, Notre Dame University - Louaize (NDU), Lebanon. Email: nancykanbar@yahoo.com; nkanbar@ndu.edu.lb 